\title{
Inhibition of Ascitic Ehrlich Tumor Cell Growth by Intraperitoneal Injection of Pfaffia paniculata (Brazilian ginseng) Butanolic Residue
}

\author{
Juliana Vieira ${ }^{1}$, Patricia Matsuzaki ${ }^{1}$, Márcia Kazumi Nagamine ${ }^{1}$, Mitsue Haraguchi ${ }^{2}$, \\ Gokithi Akisue $^{3}$, Silvana Lima Gorniak ${ }^{4}$, and Maria Lúcia Zaidan Dagli ${ }^{*}$ \\ ${ }^{1}$ Laboratorio de Oncologia Experimental e Comparada; Departamento de Patologia; Faculdade de Medicina \\ Veterinária e Zootecnia; Universidade de São Paulo; Av. Prof. Dr. Orlando Marques de Paiva, 87; 05508-900; São \\ Paulo - SP - Brasil. ${ }^{2}$ Seção de Farmacologia; Divisão de Biologia Animal; Instituto Biológico de São Paulo; Av. \\ Conselheiro Rodrigues Alves, 1.252; 04014-002; São Paulo - SP - Brasil. ${ }^{3}$ Faculdade de Pindamonhangaba; \\ Rodovia Presidente Dutra, Km 99; C. P.: 1041; Pindamonhangaba - SP - Brasil. ${ }^{4}$ Centro de Pesquisas \\ Toxicológicas; Departamento de Patologia; Faculdade de Medicina Veterinária e Zootecnia; Universidade de São \\ Paulo; Av. Duque de Caxias Norte, 225; 13635-900; Pirassununga - SP - Brasil
}

\begin{abstract}
This study aimed to investigate the effects of the administration of butanolic residue (BR) of Pfaffia paniculata by intraperitoneal route to Ehrlich ascitis tumor bearing mice. Initially, a toxicity study of P. paniculata BR was performed in which doses of $12.5 ; 25$ and $50 \mathrm{mg} / \mathrm{Kg}$ were administered by intraperitoneal injection for seven days to Swiss mice. The treatment did not show toxicity. Then, Swiss male mice received, by intraperitoneal injection, once a day, 12.5; 25 or $50 \mathrm{mg} / \mathrm{Kg}$ of $\mathrm{P}$. paniculata BR for seven days. This protocol started in the same day of tumor inoculation with $5 \times 10^{6}$ cells i.p. The treatment with butanolic residue of P.paniculata i.p caused a significant increase in the ascitic volume; however, a significant decrease in tumor cells number per $m l(p<0.05)$ was observed in P. paniculata treated mice that was followed by a numerical (although non-significant) decrease in the total numbers of tumor cells in the collected ascitic fluid. These results indicated a tumor cell inhibitory effect by P. paniculata butanolic residue in this experimental system, and indicate that topical application of this residue can be useful to control the cancer growth.
\end{abstract}

Key words: Pfaffia paniculata, Ehrlich, Intraperitoneal treatment

\section{INTRODUCTION}

The roots of Pfaffia paniculata (Brazilian ginseng) have been popularly recommended as tonic, antidiabetic and antineoplastic by folk medicine (Oliveira, 1986; Oliveira et al., 1980). The main components of this roots that have been isolated are stigmasterol, sitosterol, allantoin, besides pfaffic acid and saponins (Takemoto et al., 1983, Nishimoto et al., 1984). Pfaffic acid and the saponines have shown in vitro inhibitory effects on the growth of B-16 melanoma (Nakai et al., 1984) and phaeochromocytoma cells (Kato et al., 1993). Moreover, oral administration of $P$. paniculata preparations decreased the thymic lymphoma in mice (Watanabe et al., 2000). Many studies have

*Author for correspondence: mlzdagli@usp.br 
described the diverse effects of P.paniculata on tumor growth.

The Ehrlich tumor, derived from a mouse adenocarcinoma, has been used as a transplantable tumor model to investigate the antineoplastic effects of many substances or compounds. After the intraperitoneal inoculation of Ehrlich tumor cells, the ascitic volume increases progressively (Vincent; Nicholls, 1967). Ascitis is probably formed in consequence of tumor-induced inflammation, due to the increase in peritoneal vascular permeability (Fastaia; Dumont, 1976). The impaired peritoneal lymphatic drainage by the tumor cells (Fastaia; Dumont, 1976), the mechanic pressure exerted by progressive increase of ascitic fluid, intraperitoneal hemorrhage and endotoxemia are the other effects of Ehrlich ascitic tumor that result in the death of the animals (Harveit, 1965; Mayer, 1966).

Recently, Nagamine et al. (2008), showed that the butanolic residue of P.paniculata presented in vitro antineoplastic effects against the human neoplastic mammary lineage MCF-7 cells, causing death and growth arrest. These results led us to investigate the topical effects of this residue on tumors. Ehrlich ascitis tumor is a suitable model to accomplish this purpose. Therefore, the aim of this study was to investigate the effects of Pfaffia paniculata butanolic residue by intraperitoneal treatment in neoplastic ascitis bearing mice.

\section{MATERIAL AND METHODS}

\section{Animals}

Groups of 8- week-old Swiss male mice from the colony of the Department of Pathology of the School of Veterinary Medicine and Animal Science (SVMAS) of the University of São Paulo (USP) animal facility were used. The animals weighing $30-40 \mathrm{~g}$ at the beginning of the experiment, were housed under the conditions of controlled temperature $\left(22-24^{\circ} \mathrm{C}\right)$, humidity (45$65 \%)$ and light (12h light/12h dark, lights on at 7:00 a.m.) and received food and water ad libitum. The animals were housed and used in accordance with the guidelines of the Bioethics Committee of the SVMAS-USP.

\section{Preparation of extract, fraction and treatment regimen}

Powdered roots of $P$. paniculata were kindly provided by Prof. Dr. Gokithi Akisue. A voucher specimen of this plant was deposited in the Goro Hashimoto herbarium (São Paulo- SP, Brazil). The root powder was extracted with $95 \%$ ethanol, and the liquid so obtained was concentrated under reduced pressure at $55^{\circ} \mathrm{C}$. The resulting ethanolic extract (EE) was partitioned between butanol and water. The butanol water-soluble portion was dried at $55^{\circ} \mathrm{C}$, and kept on desiccators to yield the butanolic residue (BR). The butanolic residue was dissolved in phosphate buffered saline solution (PBS), and administered by daily intraperitoneal injections, at a volume of $0.2 \mathrm{ml}$ per animal.

\section{Ehrlich tumor}

The Ehrlich tumor was maintained in the ascitic form by the sequential passages in Swiss mice, by means of weekly i.p transplantations of $5 \times 10^{5}$ tumor cells. The animals used in this study were inoculated with $5 \times 10^{6}$ tumor cells suspended in $0.4 \mathrm{ml}$ of phosphate buffered saline (PBS) solution ( $\mathrm{pH}$ 7.2-7.4), i.p The ascitic fluid was collected using a syringe and the tumor cell count was performed in a Neubauer hemocitometer, using the Trypan Blue dye exclusion method. The suspension containing tumor cells was prepared as previously described (Dagli et al, 1992).

\section{Toxicity Study}

Groups of mice $(n=4)$ received i.p injections of BR $(12.5,25$, or $50 \mathrm{mg} / \mathrm{Kg} /$ day) or PBS (control animal) for seven days. The animals were weighed every three days. At the end of the treatment, the animals were euthanized, and liver, kidney, lung, spleen, heart, intestine and mediastinic lymph nodes were collected. Representative slices were routinely processed for embedding in paraffin; $5 \mu \mathrm{m}$ sections were stained in $\mathrm{H} \& \mathrm{E}$, and examined for possible histopathological changes.

\section{Treatment with $B R$ and quantification of Ehrlich ascitic tumor growth}

In first experiment, four groups of mice ( $n=8$ per group) received $\mathrm{BR}$ daily $(12.5 ; 25$; or $50 \mathrm{mg} / \mathrm{Kg} /$ day) for seven days, or PBS solution, under the same conditions (control group). In the second experiment, two groups of mice $(n=16$ per group) received $\mathrm{BR}$ daily $(50 \mathrm{mg} / \mathrm{Kg} /$ day) for seven days, or PBS solution, under the same conditions (control group). The animals were subsequently inoculated i.p. with Ehrlich tumor cells. The groups were sacrificed on the 8th day after the beginning of their respective treatments. The ascitic fluid volume was collected for volume 
measurement and ascitic tumor cell count. Liver, kidney, lung, spleen, heart, intestine and mediastinic lymph nodes were collected, and representative slices were routinely processed for embedding in paraffin; $5 \mu \mathrm{m}$ sections were stained in $\mathrm{H} \& \mathrm{E}$, and examined for possible histopathological changes.

\section{Statistical analysis}

Unpaired Student's t test or Mann-Whitney Test were performed for comparison between the groups. $\mathrm{P}<0.05$ was considered significant. Data are presented as mean $\pm \mathrm{SD}$.

\section{RESULTS}

\section{Toxicity Study}

There was no significant weight variation between the control group and BR-treated groups (data not shown). No evidences of hepatic or renal toxicity were found by the histopathological analysis.

\section{Effect of BR on ascitic Ehrlich tumor growth}

When ascitis Ehrlich tumor bearing mice were treated with the doses of 12.5 or $25 \mathrm{mg} / \mathrm{kg}$ of butanolic residue of P.paniculata, no alterations in the tumor growth were observed (data not shown). However, the group of mice treated with $50 \mathrm{mg} / \mathrm{kg}$ of P.paniculata butanolic residue presented significant alterations in the ascitic tumor growth. Total ascitic volume was significantly higher $(\mathrm{p}<$ 0.05 ) in the BR treated group (Table1). Tumor cell number per $\mathrm{ml}$ was significantly lower $(\mathrm{p}<0.05)$ in tumor-bearing mice treated with BR $50 \mathrm{mg} / \mathrm{Kg}$ of $P$. paniculata. Total number of tumor cells collected from $50 \mathrm{mg} / \mathrm{Kg}$ BR- tumor bearing treated mice was numerically smaller than the control group; however, this difference was not significant. The weight gain in tumor-bearing treated mice during the experiment did not differ from control group as shown in Figure 1.

Table 1 - Total ascitic volume, tumor cells per ml, and total number of cells of mice inoculated with a suspension of tumor cells $\left(5 \times 10^{6}\right.$ cells), intraperitoneally and treated with $P$. paniculata butanolic residue (BR) $(50 \mathrm{mg} / \mathrm{Kg})$ or PBS - control (ctrl) (mean \pm SD) for seven days

\begin{tabular}{|c|c|c|c|}
\hline & Total ascitic volume(ml) & Tumor cell number/ $\mathrm{ml}\left(\mathbf{1 0}^{7}\right)$ & Total number of tumor cells $\left(10^{7}\right)$ \\
\hline$\overline{B R}$ & $5.87 \pm 1.67 *^{1}$ & $28.38 \pm 16.72 *^{2}$ & $142.60 \pm 28.18$ \\
\hline ctrl & $4.14 \pm 1.42$ & $71.66 \pm 119.58$ & $176.29 \pm 41.54$ \\
\hline
\end{tabular}

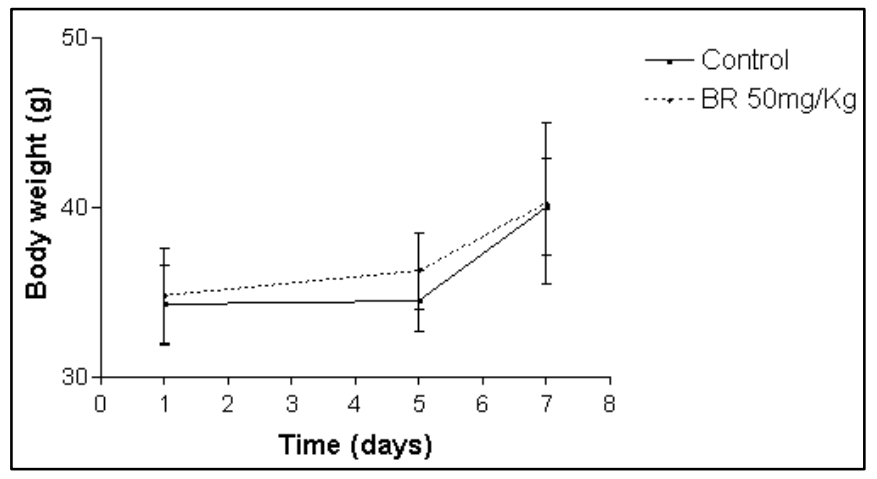

Figure 1 - Mean body weight of mice treated with $50 \mathrm{mg} / \mathrm{Kg}$ of BR (BR50), or PBS solution (control). $\mathrm{n}=16$ animals per group. 


\section{DISCUSSION}

Previous studies have shown that the Brazilian ginseng, $P$. paniculata, presents both antineoplastic (Matsuzaki et al 2003, Matsuzaki et al., 2006, Carneiro et al., 2007, Nagamine et al, 2008) and cancer chemopreventive properties (Silva et al., 2005). The whole powdered root presented antineoplastic effects against Ehrlich ascites tumor (Matsuzaki et al 2003), and chemopreventive activity in a mouse hepatocarcinogenesis model (Silva et al., 2005). The methanolic extract of P.paniculata decreased the angiogenesis in the mouse cornea model (Carneiro et al., 2007), indicating a possible antiproliferative effect. The oral administration of the butanolic residue presented inhibitory effects on Ehrlich tumor bearing mice, increasing the survival time (Matsuzaki et al., 2006) and also antineoplastic effects on mammary tumor cells MCF7 (Nagamine et al, 2008). These results led to investigate the role of the butanolic extract when administered topically in ascitis bearing mice.

Results also showed that the intraperitoneal treatment with the dose of $50 \mathrm{mg} / \mathrm{Kg}$ of butanolic residue of $P$. paniculata promoted an increase in ascitic fluid volume. This could indicate a proinflammatory role of the BR in the cited dose, probably increasing the permeability of peritoneal blood vessels. In parallel with this result, BR interestingly was able to reduce the tumor cell numbers per $\mathrm{ml}$ in ascitic fluid. This indicated a toxic effect on these cells that resulted in cell death. This result corroborated the findings of Nagamine et al., 2008, which showed a toxic effect of BR on human mammary tumor MCF cells. As a result of the diminished numbers of tumor cells per $\mathrm{ml}$, and the increase of ascitic fluid, a numerical decrease in the total number of tumor cells in the ascitic fluid was shown. This confirmed the antineoplastic properties of P.paniculata BR. Results also whowed that the same dose of BR did not induce toxicity in mice. Oral treatment with BR of $P$. paniculata caused an increase in lifespan of Ehrlich ascitis tumor bearing mice (Matsuzaki et al., 2006). Reduction of the ascitic fluid volume was also observed. However, it was difficult to establish a comparison with the present study, because the administration of this residue by oral route required metabolization in liver, and the amount of active components that achieved tumor cells was reduced in comparison with topical, i.p administration. There is a complex relationship between the components normally present in the plant extracts. The active components of $P$. paniculata are likely to be present in the butanolic residue.

The present results suggest that the butanolic residue present a topical inhibitory effect on tumor growth and the next step would be its use in topical solutions to treat, for example, skin tumors.

\section{ACKNOWLEDGEMENTS}

Juliana Vieira was the recipient of a fellowship from Fundação de Amparo à Pesquisa do Estado de São Paulo, Brazil (FAPESP 05/50220-0). This work also received grants from Conselho Nacional de Desenvolvimento Científico e Tecnológico (CNPq) and FAPESP.

\section{RESUMO}

Neste estudo, foi avaliado o efeito do tratamento intraperitoneal com Resíduo Butanólico de Pfaffia paniculata, sobre o crescimento do Tumor de Ehrlich, forma ascítica. Foram utilizados dois grupos de 15 camundongos cada, sendo um grupo controle e o outro grupo tratado com RB $50 \mathrm{mg} / \mathrm{Kg}$. Todos os animais foram inoculados intraperitonealmente, com $5 \times 10^{6}$ células tumorais $\mathrm{O}$ tratamento iniciou-se no mesmo dia da inoculação do tumor. Assim, os animais receberam diariamente, por via intraperitoneal, $0,1 \mathrm{ml}$ de $\mathrm{RB}$ na concentrações $50 \mathrm{mg} / \mathrm{Kg}$, ou PBS como controle. Após 7 dias da inoculação do tumor, os animais foram eutanasiados e foi colhido o fluído ascítico total, para a contagem do número de células tumorais presentes neste fluído e estudo da morfologia destas células. Neste experimento observou-se aumento significante da quantidade de fluido ascítico nos animais tratados com RB, e diminuição significativa em relação ao número de células tumorais $/ \mathrm{ml}$ e células tumorais totais, presentes no fluído ascítico, comparativamente com os animais controle. Estes resultados sugerem efeito inibitório tópico do RB levando à morte as células neoplásicas. 


\section{REFERENCES}

Carneiro CS, Costa-Pinto FA, da Silva AP, Pinello KC, da Silva TC, Matsuzaki P, Nagamine MK, Górniak SL, Haraguchi M, Akisue G, Dagli ML. (2007), Pfaffia paniculata (Brazilian ginseng) methanolic extract reduces angiogenesis in mice. Exp Toxicol Pathol., 58 (6):427-31.

Dagli, M. L. Z.; Guerra, J. L.; Saldiva, P. H. N. (1992), An experimental study on the lymphatic dissemination of the solid Ehrlich tumor in mice. Braz. J. Vet. Res. Anim. Sci, 29 (1), 97-103.

Fastaia J., A. Dumont. (1976), Pathogenesis of ascites in mice with peritoneal carcinomatosis. J Natl Cancer Inst. 56, 547-549.

Hartveit F. (1965), The imediate cause of death in mice with Ehrlich ascites carcinoma. Acta Path Microb Scand, 65, 359-365.

Kato, S.; Hoshikawa-Fujimura, A.Y.; Martin, R. C. T.; Sakahara, S. N.; Bruneto, F. A.; Toledo, S. P. A. (1993), Ação da Pfaffia paniculata (Martius) Kuntze em células de fibroblasto normal e feocromocitoma. Reunião anual da federação de biologia experimental, 8 Caxambu, p.283.

Matsuzaki P., Gokithi A., Oloris C.S., Gorniak L.S., Dagli M.L.Z.. (2003), Efecct of Pfaffia paniculata (Brazilian ginseng) on the Ehrlich tumor in its ascitic form. Life Sciences, 74, 573-579.

Matsuzaki P, Haraguchi M, Akisue G, Oloris SC, Nagamine MK, da Silva TC, Sakai M, Fonseca ED, Palermo-Neto J, Lima Gorniak S, Dagli M.L. (2006), Antineoplastic effects of butanolic residue of Pfaffia paniculata. Cancer Lett., 238 (1):85-9.

Mayer K.D.. (1966), The pathogenicity of the Ehrlich ascites tumor. Brit J Exp Path, 47, 537-544.

Nagamine MK, da Silva TC, Matsuzaki P, Pinello KC, Cogliati B, Pizzo CR, Akisue G, Haraguchi M, Górniak SL, Sinhorini IL, Rao KV, Barbuto JA, Dagli ML. (2009), Cytotoxic effects of butanolic extract from Pfaffia paniculata (Brazilian Ginseng) on cultured human breast cancer cell line MCF-7. Exp Toxicol Pathol., 61 (1):75-82.
Nakai, S.; Takagi, N.; Miichi, H.; Hayashi, S.; Nishimoto, N.; Takemoto, T.; Kizu, H. (1984), Pfaffosides and nortriterpenoid saponins from Pfaffia paniculata. Phytochemistry, 23 (8), 1703-5,

Nishimoto, N.; Nakai, S.; Takagi, N.; Hayashi, S.; Takemoto, T.; Odashima, S.; Kizu, H.; Wada, Y. (1984) Pfaffosides and nortriterpenoid saponins from Pfaffia paniculata. Phytochemistry, 23 (1), 139-42

Oliveira, F. (1986), Pfaffia paniculata (Martius) Kuntze - O ginseng brasileiro. Revista Brasileira de Farmacognosia, 1, 86-92.

Oliveira, F.; Akissue, G.; Akissue, M.K. (1980), Contribuição para o estudo farmacognóstico do"ginseng brasileiro" Pfaffia paniculata (Martius) Kuntze. Anais de Farmácia e Química, São Paulo, 20, 261-77.

Vincent P.C., Nicholls A.. (1967), Comparision of the growth of the Ehrlich ascites tumor in male and female mice. Cancer Research., 27, 1058-1065.

Silva, TC, Silva AP, Akisue G, Raspantini PC, Matsuzaki P, Nagamine MK, Avanzo JL, Fukumasu H, Haraguchi M, Górniak SL, Dagli MLZ. (2005), Inhibitory effects of Pfaffia paniculata (Brasilian ginseng) on preneoplastic and neoplastic lesions in a mouse hepatocarcinogenesis model. Cancer Lett., 226 (2), 107-13.

Takemoto, T.; Nishimoto, N.; Nakai, S.; Takagi, N.; Hayashi, S.; Odashima, S.; Wada, Y. (1983), Pfaffic acid, a novel nortriterpene from Pfaffia paniculata. Kuntze. Tetrahedron letters, 24 (10), 1057-60

Watanabe, T.; Watanabe, M.; Watanabe, Y.; Hotta, C. (2000), Effects of oral administration of Pfaffia paniculata on incidence of spontaneous Leukemia in AKR/J mice. Cancer Detec and Prev, 24 ( 2), 173-8,.

Wheatley D.N, Ambrose E.J, Easty G.C. (1963),Infiltration of Intra-Abdominal Organs by Ascites Tumors. Nature., 199,188-9. 